\title{
DEGREES OF STATELESSNESS: CHILDREN OF RETURNED MARRIAGE MIGRANTS IN CAN THO, VIETNAM
}

\author{
SUSAN KNEEBONE, BRANDAIS YORK AND SAYOMI ARIYAWANSA*
}

\begin{abstract}
In this article, we consider the issue of the status of children of international marriage migrants who are returned to Vietnam following a failed marriage in another country. We argue that many of these children can considered to be de facto stateless due to their lack of 'effective nationality' in Vietnam. While the children, ethnically, are 'half Vietnamese' their legal status is often precarious in Vietnam as many of them hold a foreign nationality. Although their situations vary, we argue that their cases fall on a spectrum of different degrees of statelessness. In many cases their lack of household registration - ho khau — has resulted in 'ineffective nationality', which we argue is de facto statelessness. In this article, we present findings from data collection undertaken between 2015-19 in Can Tho, Vietnam and suggest how law and policy could address the issue. We argue that our findings provide a useful case study for considering the importance of effective nationality, which we situate within the broader conceptual debate surrounding de facto statelessness.
\end{abstract}

\section{TABLE OF CONTENTS}

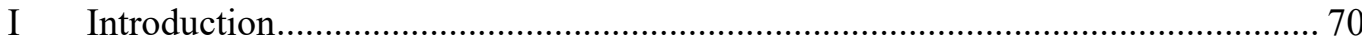

II 'De Facto' Statelessness or 'Ineffective Nationality': A Conceptual Analysis ...... 72

III Case Study: The Children of Returned Marriage Migrants from Can Tho.............. 77

A The Context: Marriage Migration............................................................... 77

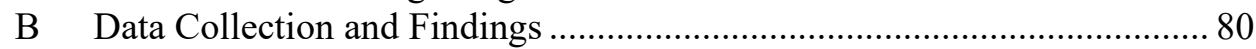

C The Four Categories of Children of Returned Marriage Migrants ............. 81

1 Children with Vietnamese Nationality ............................................ 81

2 Children with Foreign Nationality ................................................. 83

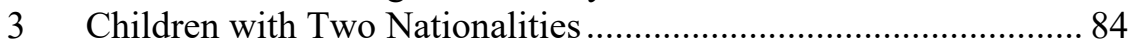

4 Children (from China) Who Are Undocumented............................ 85

IV National Identity: Household Registration, Nationality Laws and

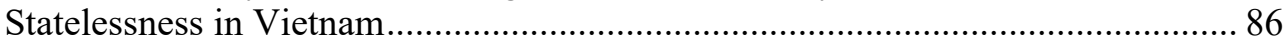

A The Household Registration System as De Facto Nationality.....................86

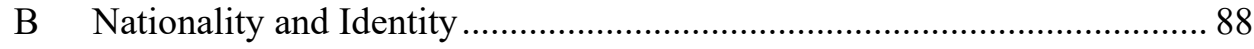

C Recognition of De Jure Statelessness in Vietnam ...................................... 91

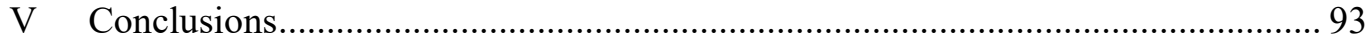

* This paper is an outcome of an Australia Research Council ('ARC') funded Discovery Project entitled, 'Development of a Legal Framework for Regulation of International Marriage Migration' for which Professor Susan Kneebone is Chief Investigator and Brandais York and Sayomi Ariyawansa are Research Assistants employed under the grant. The paper is based upon a consultancy report dated December 2017 prepared by co-researcher Dr Tran, Thi Phung Ha from Can Tho University under the ARC grant, and additional data collected by the authors in November 2015 and May 2017, August 2018 and April 2019. We gratefully acknowledge the support of the ARC and the work of Dr Tran and her research team. Thanks also to Hoang, Thi Tue Phuong for her assistance with organising interviews in Ho Chi Minh City in November 2015, and of Hoang and Thomas Harré for research associated with this paper. 


\section{INTRODUCTION}

The issue of stateless children is a prominent issue in Asia in the context of the children of migrant workers stemming from restrictions on birth registration, ${ }^{1}$ and on access to nationality or citizenship in the host country in which their parents work. ${ }^{2}$ It also arises in the context of in situ populations such as the Rohingya people in Myanmar who are denied citizenship. A large focus of measures to address the statelessness of such children is on addressing the shortcomings of laws that discriminate against them as de jure stateless persons under the 1954 Convention Relating to the Status of Stateless Persons ('1954 Convention') which defines statelessness in terms of lack of nationality. ${ }^{3}$ In the European context, the European Network on Statelessness has also identified issues around adoption and surrogacy of children as needing attention. ${ }^{4}$ However, problems relating to the status of returned children of marriage migrants, which is the subject of this article, are not currently a focus of efforts to address the statelessness of children. Whilst our case study involved 206 'bi-racial' 5 or bi-national children from 45 families, these problems are replicated in other 'sending' counties in Southeast Asia, including the Philippines. ${ }^{6}$

Marriage migration within the Asian region has long been discussed within the context of socio-economic conditions and the consequences for the women involved. ${ }^{7}$ Since the early 2000 s, Vietnam has been the primary source country for Southeast Asian marriage migrants. Every year thousands of women leave Vietnam (primarily from the southern Mekong Delta region) for Taiwan or South

1 United Nations High Commissioner for Refugees, Expert Meeting: Interpreting the 1961 Statelessness Convention and Preventing Statelessness among Children (Summary Conclusions, 2011) <https://www.unhcr.org/4e847ecf9.pdf $>$.

2 Susan Kneebone, 'Transnational Labour Migrants: Whose Responsibility?' in Fiona Jenkins, Mark Nolan and Kim Rubenstein (eds), Allegiance and Identity in a Globalised World (Cambridge University Press 2014).

3 Defined as 'individuals not considered as nationals by any State under the operation of its law': Convention Relating to the Status of Stateless Persons, opened for signature 28 September 1954, 360 UNTS 117 (entered into force 6 June 1960) ('1954 Convention'). See also Hugh Massey, 'UNHCR and De Facto Statelessness' (United Nations High Commissioner for Refugees, Legal and Protection Policy Research Series, March 2010) 298 $<$ https://www.unhcr.org/protection/globalconsult/4bc2ddeb9/16-unhcr-de-factostatelessness-hugh-massey.html>.

4 European Network on Statelessness, No Child Should Be Stateless (Report, 2015) $<$ https://www.statelessness.eu/sites/www.statelessness.eu/files/ENS_NoChildStateless_final .pdf $>$.

5 Susan Kneebone, 'Nationality and Identity in Regulation of International Marriage Migration in Southeast and East Asia: Children as Pawns of the State?' (Research Paper No 734, $\begin{array}{lllll}\text { University of } & \text { Melbourne, } & 1 & \text { August }\end{array}$ $<$ https://papers.ssrn.com/sol3/papers.cfm?abstract_id=2816750>.

6 See Maruja M B Asis and Karen Anne S Liao (eds), Moving Portraits: Life Stories of Migrant and Multicultural Families in Asia (Scalabrini Migration Center 2017).

7 Literature covering marriage migration in Asia is a diverse socio-focused research. Literature that includes Vietnam: Melody Chia-Wen Lu and Wen-Shan Yang, 'Introduction' in Melody Chia-Wen Lu and Wen-Shan Yang (eds), Asian Cross-Border Marriage Migration: Demographic Patterns and Social Issues (Amsterdam University Press 2010); Nicole Constable (ed), Cross-Border Marriages: Gender and Mobility in Transnational Asia (University of Pennsylvania Press 2005); Gavin W Jones and Kamalini Ramdas (eds), (Un)Tying the Knot: Ideal and Reality in Asian Marriage (Singapore University Press 2004). 
Korea as marriage migrants. ${ }^{8}$ However, not all marriages result in successful, long-term unions. Each year, many Vietnamese women repatriate back home after divorce and/or separation from their Taiwanese or Korean husbands. ${ }^{9}$ In recent years, the women have returned home increasingly accompanied by children born from these marriages. The children born in Taiwan, Korea and (more recently) China receive nationality through the jus sanguinis laws of their countries of birth. However, due to difficulties in formalising legal arrangements for divorce and custody, ${ }^{10}$ many of these children travel to Vietnam without valid legal paperwork or documentation, and without parental understanding of the legal requirements for their migration. As a result, many of the children have precarious legal status and are in danger of facing a life on the fringes of society. Although their situations are varied, we argue that these cases fall on a legal spectrum of different degrees of de facto statelessness. In many cases their lack of household registration - ho khau — has resulted in 'ineffective nationality', which we argue is de facto statelessness as it results in a lack of social rights and raises serious concerns about the future status of the children and their livelihoods. We further argue that efforts to solve statelessness, which include prevention through procedural measures, should extend to de facto statelessness.

In Part I of this article we set out our conceptual framework; in Part II we describe our data collection and explain our case study in more detail. We explain how it has expanded our understanding of de facto statelessness through an analysis of Vietnam's current nationality laws. In Part III we explain the significance of the ho khau system and focus on Vietnam's nationality laws and responses to the issue of statelessness. We set out the gaps in the existing legal framework as they apply to the children of returned marriage migrants. In conclusion, we canvass possible measures and procedures which could address issues of de facto statelessness in this context.

Briefly, the research uncovered four groups of children. It is important to stress that these children are not de jure stateless (or at least it was assumed they were not) but suffer disadvantage and discrimination because of their lack of legal and or effective Vietnamese nationality. This is primarily because of the difficulties in registering returned children for ho khau as explained in Part III. But further, as explained in Part I, children have particular rights under international law to a nationality and identity. Although we did not focus on these rights in our current data collection, they are issues which underpin our understanding of de facto statelessness in this context.

8 The numbers vary according to different sources each year and are most consistent within receiving countries. Although the Vietnamese government does not publish marriage migration statistics according to region or province, interviews with stakeholders in the Delta estimate that approximately 1,000 women were leaving the Mekong Delta region as marriage migrants on an annual basis as recently as August 2018. Brandais York and Sayomi Ariyawansa, Interview with Ms Tham, Chairman of Policy, Women's Union, Can Tho City, (Can Tho, Vietnam, 3 August 2018).

9 In both Korea and Taiwan, the nationality and immigration laws have responded to problems caused by high divorce rates and 'domestic violence' in international marriages, which are well documented: Susan Kneebone, 'Transnational Marriage Migrants and Nationality: the Cases of South Korea and Taiwan' (Conference Paper, International Academic Conference, November 2017).

10 ibid. See also Hyun Mee Kim, Shinhye Park and Ariun Shukhertei, 'Returning Home: Marriage Migrants' Legal Precarity and the Experience of Divorce' (2017) 49(1) Critical Asian Studies 38. 
The first group are children who claim Vietnamese nationality (whilst at the same time in some cases still holding their father's nationality). This group numbered 67 (out of 206). In relation to this group it appears that Vietnamese nationality has been obtained through possibly fraudulent means in order to secure permanent registration under the ho khau system for the children. The second group is the largest (136 out of 206) and hold only the nationality of their father: they are not registered. For this second group the claim that they lack effective nationality is strong. Thirdly, there were two children who identified as having two nationalities; that of their father's nationality and the mother's Vietnamese nationality. Finally, the fourth group of three children were born in China and had returned home without any proof of their birth (although it is potentially available). We argue that these four groups manifest different vulnerabilities both currently and in the future. For this reason, we describe the case study as involving 'degrees of statelessness'.

The issues related to these 'returned' children result from gaps in policies and laws, lack of understanding of the laws and inconsistencies in application of the laws. The results of our research show that the context allows for a high degree of discretion to be exercised in applying the laws and policies described below. As a result, these cases raise questions about the adequacy of national and local responses to the issue, and consistency between levels of administration. We argue that there is a need for further investigation into this underexplored consequence of the phenomenon of marriage migration in this region.

\section{II 'De FACTO’ StATELESSNESS OR 'INEFFECTIVE NATIONALITY’: A}

\section{CONCEPTUAL ANALYSIS}

The 1954 Convention defined statelessness in terms of lack of nationality. ${ }^{11}$ Reflecting the historical circumstances of its drafting, it did not use the terms de jure or de facto statelessness; however de facto stateless persons have been traditionally assumed to be refugees. ${ }^{12}$ For example, the 1946 Intergovernmental Committee on Refugees defined de facto stateless persons as being 'outside the state of their nationality', ${ }^{13}$ while a 1949 United Nations Secretary-General study broadened the definition to include persons who 'having left the country of which they were nationals, no longer enjoy the protection and assistance of their national authorities'. ${ }^{14}$ The link between lack of protection and geographic separation from a person's state of origin is reflected in the definition of a refugee in the 1951 Convention Relating to the Status of Refugees ('1951 Convention'). ${ }^{15}$

11 Defined within the 1954 Convention as 'individuals not considered as nationals by any State under the operation of its law': 1954 Convention (n 3) art 1. See also Massey (n 3) 15-22.

12 Carol Batchelor, 'Stateless Persons: Some Gaps in International Protection' (1995) 7 International Journal of Refugee Law 232, 257. See also Michelle Foster and Helene Lambert, 'Statelessness as a Human Rights Issue: A Concept Whose Time Has Come' (2016) 28(4) International Journal of Refugee Law 564, 574.

13 United Nations Ad Hoc Committee on Refugees and Stateless Persons, A Study of Statelessness, (Study E/1112; E/1112/Add.1, 1 August 1949) <https://www.unhcr.org/en$\mathrm{au} /$ protection/statelessness/3ae68c2d0/study-statelessness-united-nations-august-1949-lakesuccess-new-york.html>.

14 Massey (n 3) 4.

15 See Convention Relating to the Status of Refugees, opened for signature 28 July 1951, 189 UNTS 137 (entered into force 22 April 1954); 1954 Convention (n 3) art 1A(2). 
The 1954 Convention contains the only legal definition of statelessness, which has attained the status of customary law. ${ }^{16}$ However, in recent decades the limits of this definition have been challenged in several ways. First, there is a debate over the meaning of 'nationality' under the 1954 Convention, which is related to the scope of the United Nations High Commissioner for Refugees' ('UNHCR') mandate. Secondly, there has been increasing concern for individuals lacking 'a particular nationality rather than lack of any nationality' 17 - a phenomenon also referred to as de facto statelessness. ${ }^{18}$ This issue is often discussed as one of 'effective protection' or 'effective nationality', 19 as these are persons whose nationality does not provide effective rights or protections. Our study is located within this concept of 'effective nationality' which, we argue, falls within the scope of the UNHCR's statelessness mandate which includes the prevention of statelessness. We argue that the mandate extends to issues addressing possible causes of future (de jure) statelessness such as: addressing gaps in nationality legislation, administrative obstacles to obtaining nationality, birth registration, issuance of identity documentation and determination of nationality status. ${ }^{20}$

Most literature on statelessness (particularly guidance coming directly from UNHCR) is focused on de jure statelessness or lack of nationality as defined within the 1954 Convention. ${ }^{21}$ That is, it focuses on nationality as an international law concept of a formal link to a state rather than the concept of citizenship, which is more often linked to national or municipal law, to membership of a community with attendant rights and duties. A string of scholars has argued that a broader mandate on statelessness has the potential to weaken and to undermine the authority and limits of the existing international law principles and UNHCR mandate. ${ }^{22}$

However another group of scholars has argued that the focus of statelessness studies should be expanded beyond the 'traditional' definition of de facto statelessness (as referring to persons that have left or are otherwise located outside their state of nationality). ${ }^{23}$ The 'traditional' understanding of de facto statelessness fails to address individuals residing within the state to which they have a claim to nationality but live without full protection and/or rights associated with their nationality. This would include, for example, Nepali nationals who are unable to access citizenship certificates due to Nepal's restrictive nationality laws.

16 Katia Bianchini, Protecting Stateless Persons: The Implementation of the Convention Relating to the Status of Stateless Persons across EU States (Brill Nijhoff 2018) 74.

17 Alison Harvey, 'Statelessness: The 'De Facto' Statelessness Debate' (2010) 24(3) Immigration, Asylum and Nationality Law 257, 258.

18 Open Society Institute, 'De Jure Statelessness in the Real World: Applying the Prato Summary Conclusions' (Report, March 2011) 4 $<$ https://www.opensocietyfoundations.org/reports/de-jure-statelessness-real-world-applyingprato-summary-conclusions $>$.

19 Batchelor (n 12) 233.

20 Massey (n 3) 15-22.

21 ibid 298.

22 Bianchini (n 16) 81-83.

23 Sharita Gruberg, 'De Facto Statelessness among Undocumented Migrants in Greece' (2011) 18(3) Georgetown Journal on Poverty Law \& Policy 533, 535-36. 
Some have argued that this lack of documentation has in fact resulted in 'dire consequences that amount to de facto statelessness' ${ }^{24}$

David Weissbrodt and Clay Collins link de facto statelessness to lack of human rights protection and argue that it can occur either where the affected population is in situ (as in the case of the Nepali above) or where people move and 'relinquish the services, protection and benefit of their country'.25 The dilemma of the 'traditional' view, (that de facto statelessness occurs within a migratory context), as Caia Vlieks points out, is that there is a bias in recent de facto statelessness literature towards the in situ group at the expense of migrants. Vlieks' argument is rooted in the idea that migrants are typically afforded less 'benefit of the doubt' in terms of substantiating their ties to a given state. ${ }^{26}$ This understanding seeks to broaden the idea of de facto statelessness beyond individuals who are denied citizenship in their state of birth (in situ), by expanding upon the foundational concept of nationality and arguing that ties to place or state are important, and that they are subjective and fluctuate.

These arguments for de facto statelessness are based on the idea that the quality and content of nationality (or citizenship) must be considered; that is, the issue is one of effective protection or nationality as stated above. ${ }^{27}$ They implicitly undermine the view that nationality is solely an international law and formal concept as the 1954 Convention suggests. In broader nationality scholarship there is a view as Alison Kesby argues, that nationality is both a 'territorial and legally constructed conception of place' 28 which is 'socially produced'. ${ }^{29}$ Peter Spiro argues that the 'traditional conception of international law and nationality is eroding' ${ }^{30}$ He suggests that a basic norm of non-discrimination should apply, which includes a procedural aspect; that is, "practices relating to birthright citizenship, naturalization, dual citizenship, and loss of citizenship'. ${ }^{31}$ These arguments are particularly pertinent for our Vietnamese case study as we will explain in this article. Another point to note in this context, is that in comparison to the 1951 Convention which grants rights according to the level of attachment of an individual asylum seeker to the territory in which refuge is granted, ${ }^{32}$ the 1954 Convention on stateless persons grants considerably more generous rights to stateless persons. This comparison corroborates Carol Batchelor's argument that

24 The argument is that Nepal's citizenship certificate is vital to everyday livelihood as it is related to the ability to access rights, opportunities and services afforded to Nepali citizens including formal sector employment, banking or micro-credit, birth and marriage registration and passports: Paul White, 'Reducing de facto Statelessness in Nepal' Forced Migration Review (Online, April 2009) $28<$ https://www.fmreview.org/statelessness/white>.

25 David Weissbrodt and Clay Collins, 'The Human Rights of Stateless Persons' (2006) 28(1) Human Rights Quarterly 245, 252.

26 Caia Vlieks, 'Contexts of Statelessness: The Concepts "Statelessness In Situ" and "Statelessness in the Migratory Context"" in Tendayi Bloom, Katherine Tonkiss and Phillip Cole (eds), Understanding Statelessness (Taylor \& Francis 2017) 35, 35.

27 Batchelor (n 12) 233.

28 Alison Kesby, The Right to Have Rights: Citizenship, Humanity and International Law (Oxford University Press 2012), 38.

29 ibid 14.

30 Peter J Spiro, 'Citizenship, Nationality, and Statelessness' in Vincent Chetail and Celine Bauloz (eds), Research Handbook on International Law and Migration (Edward Elgar 2014) $281,281$.

31 ibid.

32 Susan Kneebone, 'The Pacific Plan: The Provision of "Effective Protection"?' (2006) 18(3\&4) International Journal of Refugee Law 696, 702-5. 
there was not a 'thorough analysis of the problem of statelessness' 33 during the drafting of the 1954 Convention.

However, arguments that de facto statelessness should be addressed as an issue of effective protection or nationality are resisted on the basis that this conflates concepts of (international law) nationality and municipal citizenship. For example, UNHCR's senior legal advisor Hugh Massey argued in 2010 that expanding the definition of de facto citizenship beyond lack of effective nationality ${ }^{34}$ would run counter to the sovereign rights of states to determine membership of their communities. ${ }^{35}$ His argument is essentially that UNHCR should only cover those persons who fit within the strict definition of de facto statelessness or lack of nationality. ${ }^{36}$ The UN has implied that de facto statelessness should be treated similarly to that of de jure - even though the 1961 Convention on the Reduction of Statelessness ('1961 Convention') is only legally binding with respect to de jure: 'persons who are stateless de facto should as far as possible be treated as stateless de jure to enable them to acquire an effective nationality'. ${ }^{37}$ Massey's argument thus seems to stem from this tension: if de facto statelessness is too broadly expanded, the paradigm will expand beyond the scope of what UNHCR is equipped to handle, thus rendering their mandate ineffective. ${ }^{38}$

Another group of scholars shows the ambiguity of conflating de facto statelessness with municipal citizenship. In 2014, Jason Tucker challenged the very inclusion of the concept of ineffective citizenship within the statelessness discourse. ${ }^{39} \mathrm{He}$ argued that '[i]neffective citizenship does not make a person stateless, as a legal bond of citizenship remains'. ${ }^{40}$ Instead, he argues controversially for this debate to be situated in relation to citizenship rather than lack thereof, through what he calls 'de facto citizenship'. Giving the example of the de jure stateless Russians in Estonia, he discusses how de jure stateless people can enjoy rights linked to citizenship in such a way as their daily life would appear not to be impacted ('these rights include social rights, legal protection, nearly equal political rights, passports, and consular protection'). ${ }^{41}$ Some scholars have argued that such groups are so 'unaffected' by their statelessness, that they could be called 'de facto citizens' despite their lack of legal citizenship. ${ }^{42}$

However, Tucker argues that although the 'effective citizenship' qualification is seemingly 'met' in the case of Russians in Estonia, there are still consequences

33 Batchelor (n 12) 243.

34 Which he defined in accordance with above, $\mathrm{n} \mathrm{3}$, and as persons who 'have a nationality in name, but their nationality is ineffective because they are unprotected by the State of their nationality': Massey (n 3) 26. ibid; Batchelor (n 12).

36 Massey (n 3) 61.

37 ibid, quoting Convention on the Reduction of Statelessness, opened for signature 30 August 1961, 989 UNTS 175 (entered into force 13 December 1975) art 1.

38 Batchelor (n 12) 232.

39 Jason Tucker, 'Questioning De Facto Statelessness: By Looking at De Facto Statelessness' (2014) 19(1-2) Tilburg Law Review 276.

40 ibid 278 (emphasis in original).

41 ibid 280.

42 ibid. This argument mirrors Tendayi Bloom's analysis of membership. She argues that citizenship is not the only form of membership linking individuals to states in that she 'recognises noncitizenship as an often active and dynamic relationship between an individual and a State, wherever on the planet s/he is': Tendayi Bloom, Noncitizenism: Recognising Noncitizen Capabilities in a World of Citizens (Routledge 2018) 11. 
to their de jure stateless status because they have no legal claim to any of these protections (and that these rights and protections can be 'taken away' without warrant or right to disagree). ${ }^{43}$ Thus, for Tucker, the most important element is the 'legal bond' aspect by which the state is bound to take the rights of citizens seriously: de facto citizens may face obstacles in challenging denial of rights and in correcting their statelessness. Thus, he argues, 'by broadening the definition to include de facto statelessness ... we weaken one of the only means by which we have to challenge statelessness itself' ${ }^{44} \mathrm{He}$ focuses on the need for de facto stateless persons to have access to procedures to assert their rights.

Katherine Tonkiss has argued that the conflation between (international) nationality and municipal citizenship has perpetuated the occurrence of statelessness. ${ }^{45}$ Tonkiss reframes the debate by insisting that all claims for the rights of stateless persons that do not challenge the construction of citizenship as inherently linked to a national 'imaginary social category of membership' are selfdefeating. ${ }^{46}$ This perspective is important in that it adds a new element to the discussion that allows for a critical approach to how states construct their citizenship laws, and what these constructions might mean for persons that may not have what is perceived as a legitimate attachment to a given state. While not necessarily arguing for a rejection of the nation state (or nationality) concept, Tonkiss' reframing proposes an alternate approach to statelessness that views national identity as important to the meaning of 'nationality'. This begs the question of how an individual that may have ties to more than one nationality might self-identify or be legally classified, that is, she reminds us of another issue which the statelessness debate needs to cover, namely the issue of dual-nationality. These issues of national identity and dual citizenship or nationality are also very pertinent to our Vietnamese case study of children of returned marriage migrants. Further, as we discuss in this article, the concept of nationality, or citizenship, in socialist Vietnam incorporates the institution of household registration or ho khau. Lack of household registration results in lack of effective protection for many in this cohort.

Our case study involves children with 'ineffective' nationality: they may have the foreign nationality of their father but are currently residing in their mothers' state of nationality or citizenship: Vietnam. As children, they have a higher level of vulnerability as migrants that at present is not being addressed. Further, in the case of children the issues of nationality and identity are intertwined. The Convention on the Rights of the Child 1989 ('CRC'), ${ }^{47}$ arts 7 and 8, contain provisions which collectively confer independent rights of nationality and identity upon a child which are particularly important to those born to an international marriage. $C R C$ art 7(1) creates a right of a child to be registered and named from birth, and the right to acquire a nationality. The objective of this provision as art $7(2)$ suggests, is to prevent statelessness, but art 7(1) also refers to the 'right to know and be cared for by his or her parents' — 'as far as possible'. It has been

43 Tucker (n 39) 281.

44 ibid.

45 Katherine Tonkiss, 'Statelessness and the Performance of Citizenship-As-Nationality' in Tendayi Bloom, Katherine Tonkiss and Phillip Cole (eds), Understanding Statelessness (Taylor \& Francis 2017) 241.

46 ibid.

47 Convention on the Rights of the Child, opened for signature 20 November 1989, 1577 UNTS 3 (entered into force 2 September 1990). 
accepted that the $C R C$ provision is designed to promote recognition of a child's legal personality and identity; that the child should be respected as a person in their own right. 48

Although the debate around the concept and meaning of statelessness and the scope of the UNHCR mandate has not been resolved, a consensus has formed that although states are compelled by the law of statelessness to assist de jure stateless persons, they are only 'encouraged' to assist de facto stateless persons. ${ }^{49}$ Scholars such as David Baluarte have — as recently as 2017 - demonstrated that international bodies have repeatedly declined to extend the legal definition of statelessness to include those within de facto categories. This consensus has instead shown that challenges related to ineffective nationality are better approached by raising individual cases with the related country as a violation of human rights. ${ }^{50}$

Those arguing for a broader understanding of de facto statelessness as lack of 'effective nationality' have posited that individuals facing obstacles to the acquisition of nationality should be included within the scope of statelessness law. These obstacles of course differ depending on circumstances, but could include difficulty registering births, difficulty accessing any form of legal documentation (such as birth certificate or household registration) or difficulty claiming access to any of the rights and protections usually afforded by nationality. ${ }^{51}$ From this perspective, individuals falling under this category may not be stateless under legal definitions, but could suffer from similar (if not the same) difficulties related to a lack of access, rights and protections. In our view a procedural approach to addressing discrimination that arises from de facto statelessness is an appropriate compromise of these competing views.

\section{Case Study: The ChILdRen of Returned Marriage Migrants From}

\section{CAN THO}

\section{A The Context: Marriage Migration}

As previously noted, Vietnam has been and is the largest source country for marriage migrants within Southeast Asia over the last two decades. Since the late 1990s, Vietnamese women have migrated abroad through marriage to many destinations, most prominently Taiwan, South Korea and also to mainland China. Until about 2003, Taiwan was the most popular destination for brides, after which

48 Ineta Ziemele, 'Article7: The Right to Birth Registration, Name and Nationality, and the Right to Know and Be Cared for by Parents', in Andre Alen et al (eds) A Commentary on the United Nations Convention on the Rights of the Child (Martinus Nijhoff 2007) 1, 1.

49 David C Baluarte, 'The Risk of Statelessness: Reasserting a Rule for the Protection of the Right to Nationality' (2017) 19(1) Yale Human Rights and Development Law Journal 47, 7980 .

50 ibid 82.

51 Massey (n 2) 16. 
it was superseded by South Korea. ${ }^{52}$ International marriage migration to Taiwan was thus the first 'wave'. ${ }^{53}$ While both trends peaked and began to level off around 2010, women continue to migrate through marriage to both destinations. Although statistics vary according to sources, in 2012 the International Organization for Migration estimated that 142,424 Vietnamese women had married South Korean men between 2002 (455 marriages) and 2010 (35,355 marriages). ${ }^{54}$ In the year 2012 the Vietnamese government estimated that around 40,000 Vietnamese women had moved to South Korea. ${ }^{55}$ By 2015, the total number of Vietnamese women who had married Taiwanese or South Korean men and migrated abroad was quoted to be as high as $170,000 .{ }^{56}$

In more recent years, mainland China has increasingly become another popular destination for marriage migration as well. From Vietnam, this has historically been a cross-border issue between Vietnam's northern region and China's southernmost provinces, Guang $\mathrm{Xi}$ and Yunnan. ${ }^{57}$ Driven by a female deficit in China, data collected in 2005 documented a trend involving unusually high numbers of women from Vietnam's northern provinces being trafficked into China for marriage. ${ }^{58}$ However, women from the Mekong Delta have also been recorded as migrating through marriage to mainland China in recent years. This trajectory of marriage migration remains under-researched, and statistics remain

52 Danièle Bélanger, 'Contribution of Women Marriage Migrants to Their Families of Origin in Rural Vietnam' (Conference Paper, International Union for the Scientific Study of Population XXVI International Population Conference, 30 September 2009); Hee-Kang Kim, 'Marriage Migration between South Korea and Vietnam: A Gender Perspective' (2012) 36(3) Asian Perspective 531. This shift reflected both Taiwan's harsh nationality laws which left thousands of marriage migrants stateless, as well as changes to South Korea's visa system which gave work rights to the Vietnamese wives: Kneebone, 'Transnational Marriage Migrants and Nationality' (n 9).

53 Hong-Zen Wang and Shu-Ming Chang, 'The Commodification of International Marriages: Cross-Border Marriage Business in Taiwan and Viet Nam' (2002) 40(6) International Migration 93.

54 Jung-Eun Oh et al, Migration Profile of the Republic of Korea (Report, International Organization for Migration, January 2012) $<$ http://publications.iom.int/system/files/pdf/mp_korea.pdf $>$.

55 Ministry of Foreign Affairs Viet Nam, Review of Vietnamese Migration Abroad (Review Report, May 2012) 19 ('Vietnamese Migration Abroad') $<$ http://www.un.org.vn/en/publications/doc_details/387-review-of-vietnamese-migrationabroad.html>.

56 Trần Thị Thu Lương, 'Một số vấn đề xẫ hội và văn hóa trong việc xây dựng nông thôn mới ở Đồng bằng Sông Cửu Long nhìn từ hiện tượng phụ nữ nông thôn lấy chồng nước ngoài. Tạp chí phát triển Khoa học và công nghệ' [A Number of Social and Cultural Issues in the Construction of New Rural Areas in the Mekong Delta Viewed from the Phenomenon of Rural Women Married Abroad] (2012) 15(2) Journal of Science and Technology Development 31, 31-47, cited in Susan Kneebone and Nguyen Anh Minh,'International Marriage Migration: Researching on Bi-Racial Children in Divorced Families: A Case Study in Vietnamese Mekong Delta'(Draft Paper, University of Melbourne). A copy of this paper is on file with the authors.

57 Le Bach Duong, Danièle Bélanger and Khuat Thu Hong, 'Transnational Migration, Marriage and Trafficking at the China-Vietnam Border' in Isabelle Attane and Christophe Guilmoto (eds), Watering the Neighbours Garden: The Growing Demographic Female Deficit in Asia (Committee for International Cooperation in National Research and Demography 2007) 393, 393; Susan Kneebone et al, Survivors of Trafficking from North Vietnam: Psychological and Social Consequences (Report, SHARE, February 2015).

58 Duong, Bélanger and Hong (n 57). 
unconsolidated and limited. Our findings include evidence that it may be increasing. 59

Writing in 2005, Nicole Constable observed that the contemporary patterns of marriage migration in Asia reflected the gendered nature of the movement, noting that the majority of the "women move from poorer countries to wealthier ones, from the less developed global "south"; to the more industrialized "north". 60 Since the early beginnings of research on marriage migration within the region, many assumptions have been made regarding the motives of the women - which stem from the connection between poverty, opportunism and a presumed lack of agency. These assumptions have in turn fed into increasingly stringent regulation within receiving states, particularly in terms of nationality laws. ${ }^{61}$ Official state responses have slowly evolved into acceptance of marriage migration as a development strategy for the women, ${ }^{62}$ and the government has responded to issues of de jure statelessness of this cohort. However, the laws and policies of Vietnam have not kept pace with the issues raised by returned children of the marriages.

Can Tho is the fourth largest city in Vietnam, nestled in the heart of the Mekong Delta. With a population of just over 1.5 million, Can Tho is the largest city in the Mekong Delta and an important economic hub for south Vietnam - second only to Ho Chi Minh City. The Can Tho region - which consists of Can Tho City and five surrounding provinces - is largely known for tourism due to its picturesque rolling rice fields, rural canals and floating markets. However, the region is also characterised by large-scale poverty and as a result, has a high rate of emigration, including through marriage migration. Can Tho is the region from which the largest number of Vietnamese women who migrate through marriage originate (approximately 100 per month regionally), and consequently, the region is likely to hold the highest number of marriage migrants to have repatriated back from overseas. ${ }^{63}$

Although many women find relative 'success' in marriages that result from the above trends, many do not. In addition to standard marital breakdowns, marriage migrants are also vulnerable to physical and emotional abuse, forced labour and exploitation. If and/or when these marriages subsequently break down, some women may choose to stay abroad. However, many are either forced or choose to return to Vietnam. As these families mature, increasingly more women have been returning to their hometowns with children from these unions. However, the women often choose to take the children back to Vietnam without obtaining

59 Tran Thi Phung Ha, 'Draft Report for the Project: Development of a Legal Framework for International Marriage Migration (IMM)' (Draft Paper, Can Tho University, December 2017). A copy of this paper on file with the authors.

60 Constable (n 7) 4.

61 In Taiwan marriage migrants seeking citizenship until 2016 were required to renounce their previous citizenship prior to applying for and acquiring Taiwanese citizenship. This resulted in many women becoming stateless as they were unable to complete the naturalisation process or subsequently lost Taiwanese nationality on death or divorce of the husband. The majority of the women affected were Vietnamese. See Kitty McKinsey, 'Divorce Leaves Some Vietnamese Women Broken-Hearted and Stateless' (United Nations High Commissioner for Refugees, 14 February, 2007) <http://www.unhcr.org/45d324428.html>; Kitty McKinsey 'Vietnam Sets Pace for Asia with New Law to Prevent Statelessness' (United Nations High Commissioner for Refugees, 1 July 2009) <http://www.unhcr.org/4a4b809d9.html>.

62 Vietnamese Migration Abroad (n 55) 39-40.

63 This estimation derives from interviews conducted by Dr Ha and her team and reflects their estimations: Ha (n 59). 
custody or permission from their fathers to take them abroad, and without possession of their legal documentation. Because of the timeline of migration trends, the children that resulted from marriage migration to Taiwan are the oldest, followed by those from Korea and then China. Currently, most of these children remain in primary school, meaning the full scope of their legal problems may have yet to reveal themselves. We believe this issue will continue to develop and increase in severity as the children involved mature.

\section{B Data Collection and Findings}

The research presented in this paper was conducted by a team of researchers in and around Can Tho over a two-year period. ${ }^{64}$ Through in-depth fieldwork in two districts in the Can Tho region, our project was able to not only substantiate our hypothesis that some of the children involved in these cases (especially groups 2, 3 and 4) face difficulties in accessing social rights within the Vietnamese legal and administrative system, but also that they all potentially face future challenges in asserting economic and political rights. Our research was carried out over three stages from 2015-18 and included data collection with provincial and district level officials, academic and non-governmental stakeholders and families of returned children (rather than their mothers).

Interviews conducted with non-migrant stakeholders consisted of semistructured interviews intended to help gauge the extent of the problem, for which no formal statistics currently exist. The existing statistics rely on migrant's selfidentification with the Ministry of Justice and are thought to capture only a limited number of women who have returned from marriage migration. The numbers recorded by government officials are only collected from families who report difficulties or apply for registration for themselves and/or the children. Because there is no streamlined approach to data collection on this issue at either the national or local level, each department within each province has different statistics, meaning within any given district there are a variety of different numbers to represent the same group of people. Because of this inconsistency in statistical accuracy, it is impossible to know the total number of women who have returned to the Delta with 'bi-racial' children as a result of marriage migration. ${ }^{65}$ Although several of our research subjects suggested that there could be 'hundreds of thousands' of bi-racial children currently living permanently in southern Vietnam, our research indicates that this number would be closer to somewhere in the thousands.

Our survey captured information regarding the lived realities and legal status of 45 families with bi-racial children within two districts. ${ }^{66}$ These families supported 206 bi-racial children living permanently in these districts. Based on our scoping research, we estimate that this number reflects a significant fraction of the total cases within these two districts; yet there are 126 districts in total within the five provinces of the Mekong Delta region alone.

64 ibid. Primary data was collected and translated by Tran Thi Phung Ha: Ha (n 59).

65 We use the term 'bi-racial' here to refer to children born of a Vietnamese mother and either Taiwanese, Korean or Chinese father.

66 In the vast majority of cases, interviews were conducted with grandparents of the children in question. Migrant mothers often leave their children with grandparents in order to re-migrate either internally in Vietnam or abroad. 
Interviews with family respondents (rather than the returned mothers) utilised a questionnaire style survey, accompanied by short interviews for each respondent to capture both quantitative and qualitative information regarding the nationality status of the children of returned marriage migrants. The findings presented below reflect important confirmation of our initial hypothesis that the children of marriage migrants will soon become an important group of interest within statelessness scholarship.

\section{The Four Categories of Children of Returned Marriage Migrants}

We have identified the following four categories or groups of children of returned marriage migrants in the Can Tho region who may fall within the spectrum of de facto stateless: children with Vietnamese nationality; children with foreign nationality; children with two nationalities; and children who are undocumented.

Typically, children from all four categories will be left by their mothers with relatives in a village or community which is far from administrative centres. The mothers then move to urban areas to secure employment. A recent article in the Vietnamese press highlights some of the issues affecting Vietnamese mothers and their children that follow the breakup of foreign marriages. It refers to 'many children who have foreign names and nationality in the Mekong Delta area, whose mothers brought them home after "broken nuptials". It points out that:

In Vietnam, the children apparently have no chance to be close to their fathers and neither their mothers who often leave the hometown to find jobs in other localities. 67

As we outline further below, our findings suggest a correlation between de facto statelessness and a lack of permanent registration under the household registration or ho khao system in Vietnam. There are concerns about how their legal status is determined under Vietnamese nationality laws and in practice, and the long-term consequences of this. Although, for the most part, younger children are able to attend primary school and obtain access to basic health care, this is the result of ad hoc policy decisions at the provincial level, as noted below. At present, there is no national policy concerning the children of returned marriage migrants and, as outlined below, there are gaps in the existing legal framework concerning the determination of their legal status within Vietnam.

\section{$1 \quad$ Children with Vietnamese Nationality}

Whilst Vietnam's nationality laws deal with the nationality of the children of socalled 'mixed' marriages in several respects, ${ }^{68}$ the provisions are unlikely to assist children of returned marriage migrants in the scenarios we describe.

67 'Vietnam Brides in Legal Trouble after Broken Marriages with Chinese, Koreans', (Tuoi Tre News, 14 August 2014) <http://tuoitrenews.vn/features/21628/vietnam-brides-in-legaltrouble-in-broken-marriages-with-chinese-koreans $>$ (emphasis added).

68 Article 3(2) Law on Marriage and Family 2014 (No 52/2014/QH13, 2014) (Vietnam) defines 'marriage and family relations involving foreign elements' to mean a 'marriage and family relation in which at least one partner is a foreigner or an overseas Vietnamese or in which partners are Vietnamese citizens but the bases for establishing, changing or terminating that relation are governed by a foreign law, or that relation arises abroad or the property related to that relation is located abroad'. 
Article 16(1) of the Law on Vietnamese Nationality ('2008 Nationality Law') ${ }^{69}$ states that a child born inside or outside the Vietnamese territory with one parent who is a Vietnamese citizen, and the other parent is stateless at the time of his/her birth, that child has Vietnamese nationality. Article 16(1) further states that a child born inside or outside the Vietnamese territory whose mother is a Vietnamese citizen and whose father is unknown, has Vietnamese nationality. ${ }^{70}$ Thus under this first part of art 16, wherever born, a child can take the Vietnamese nationality of a parent who is a Vietnamese citizen to avoid statelessness, or where the father is unknown. As we will explain, this latter provision is often used to falsely claim Vietnamese citizenship for a returned child of marriage migrants.

Article 16(2) contains a provision which does theoretically cover the situation of returned children of marriage migrants but which also highlights a key problem. Article 16(2) states that where one parent is a Vietnamese citizen, and the other is a foreign national, the parents must agree in writing at the time of the birth registration, that the child is a Vietnamese national, for the child to be a Vietnamese national. ${ }^{71}$ If the parents fail to reach agreement and the child is born on Vietnamese territory, then the child has Vietnamese nationality. These children (born in Taiwan, South Korea or China), will have the nationality of their father and place of birth, regardless of the legality of their parents' marriage. ${ }^{72}$

Based on our findings there is no evidence that such agreements are made at the time of the birth registration; the child born in a foreign country will be registered there with the father's nationality. Indeed, one of the main purposes of marriage migration from the perspective of the receiving (father's) state is to increase that state's population. ${ }^{73}$ Thus, falsification of a birth certificate aside, this provision has little practical effect on the nationality of a returned child of marriage migrants. There is no provision for what should occur if agreement is not reached - and what should occur if the child's mother (as is usually the case) decides to return to Vietnam with her child who, due to lack of written agreement at birth, is not Vietnamese. This is the source of much confusion - and, as our data has revealed, some inventiveness - in seeking to register the child within the ho khau system and ensuring they are able to access social services, such as public education. Permanent registration under the ho khao system affords access to many of the rights associated with effective citizenship.

However, despite these difficulties, there are a number of children of returned marriage migrants living in the Delta who claim to hold Vietnamese nationality. We found that at least 67 of the total 206 children included in our study hold Vietnamese citizenship documentation. Accordingly, in relation to this first category our findings suggest that these children are either:

- born overseas to a Vietnamese mother and a non-Vietnamese father, however their mothers typically do not bring their child's foreign identity documents (or, have been refused access to the documentation or the mother conceals it), and claim falsely that the father is unknown in order to obtain Vietnamese nationality for their child to comply with art 16(1) of the

69 (No 24/2008/QH12, 2008) (Vietnam) ('2008 Nationality Law’).

70 ibid.

71 ibid art 16(2).

72 In some cases of marriage migration, a legal marriage does not necessarily follow. Article 9 of the 2008 Nationality Law states that the 'marriage, divorce or annulment of unlawful marriage does not alter Vietnamese nationality of the involved parties as well as their minor children (if any)'.

73 Kneebone, 'Nationality and Identity in Regulation' (n 5). 
2008 Nationality Law. As explained above, this scenario reflects the difficulties which the mother may have had in the country of marriage in obtaining a valid divorce or custody of her child; or

- another scenario is where the child is born in Vietnam to a Vietnamese mother who has returned to Vietnam pregnant after a failed marriage abroad to a non-Vietnamese national, and their mother then falsely claims that the father is unknown (by claiming 'single mother status' on the birth certificate), as otherwise these women would face difficulties registering their child's birth because both parents are required to be listed on the child's birth certificate. This possibility exists as a result of a 2014 change in the law. ${ }^{74}$

In these ways, the mothers and families of these children find avenues to subvert the existing legal regime in order to obtain the outcome of their child being registered as a Vietnamese citizen. This is necessary because the current legal framework does not provide a simple avenue for a female returned marriage migrant to unilaterally register her child as a Vietnamese citizen (or potential Vietnamese citizen), if the father of the child is known to the mother, but there is no written agreement. However, by doing this, these children may obtain permanent registration status under the ho khao system, and are able to access government services including education and health care, although their status, being based on fraud is inherently precarious.

\section{Children with Foreign Nationality}

Our research suggests that the majority of children of returned marriage migrants fall within this category. From our study, at least 136 of the 206 children we interviewed held only foreign nationality and documentation. As explained above, children born abroad will obtain the nationality of their father if registered at birth (which is a routine practice in those countries) and will retain their foreign nationality on return to Vietnam. In some cases the mothers prefer to retain this single nationality (in contrast to the clear 'dual nationality' scenario discussed below) as they perceive this as a means of ensuring better opportunities for their children in the future. For example, they hope that their child can complete higher education in the father's country. But in many cases the mothers may be unaware of the consequences of this status, which may lead to hardships if the children remain in Vietnam as they grow to adulthood.

In relation to this category of children, the interaction between the legal framework concerning nationality and the effect of the household registration system suggests these children may be de facto stateless in Vietnam even though they retain their father's nationality. They lack an effective nationality or protection in Vietnam as they suffer considerable inconvenience and potential discrimination from this status.

In practice, children within this category can only be registered as 'temporary' rather than 'permanent' residents, as they are not Vietnamese citizens, and therefore must renew their registration every six months (and they must also renew

74 Law on Civil Status (No 60/2014/QH13) (Vietnam) art 14 ('Law on Civil Status 2014'). 
their temporary residence visa which permits them to reside in Vietnam). ${ }^{75}$ Our findings suggest that the registrations for many of these children may lapse, as it is time-consuming and can be costly to continually renew their registration. Further, due to the remote location of the children it may be logistically difficult to renew their registration. Hyun Mee Kim, Shinhye Park and Ariun Shukhertei observe that mothers may fail to renew their child's registration due to their limited understanding of the law and conclude: '[i]n the end, many children live impoverished lives with their mothers and/or relatives'. ${ }^{76}$ We also found from our research that lack of understanding of the consequences of the law was an important factor in decisions of relatives acting on behalf of the children.

Many of these children may end up being unregistered or undocumented under Vietnamese law and technically subject to deportation. ${ }^{77}$ Indeed, many of the families included within our study had been forced to allow their child's documentation to lapse, citing financial difficulties. These children are essentially living as illegal migrants in Vietnam, without any legal entitlement to the benefits of the Vietnamese social system (including public schooling — although permitted to attend at the discretion of local authorities). As a result, a lack of household registration may mean that a returned child in this category is de facto stateless - because of the lack of effective protection that is likely to ensue if a child is not registered, even if he or she has foreign nationality.

\section{$3 \quad$ Children with Two Nationalities}

In relation to the third category, being children with two nationalities, it is necessary to note, as discussed below, that the 2008 Nationality Law begins with a principle of 'single nationality' (and by implication, has a presumption against dual nationality). According to our research, despite the wide definition of 'Overseas Vietnamese' in the 2008 Nationality Law (discussed below) which may encompass the children of returned marriage migrants - in practice, dual nationality is limited to enable Vietnamese citizens who acquire Vietnamese citizenship at birth to retain their Vietnamese nationality even if they wish to acquire a second nationality through naturalisation (and it is particularly purposed towards enabling Vietnamese citizens who work or study abroad). Further, the definition encompasses the 'diaspora' community which the Vietnamese government has increasingly attempted to bring 'back to the fold' post Doi Moi (the 1986 'renovation' policy that prompted Vietnam's transition from a 'centrally planned socialist economy' 78 to a post-socialist and more open economy). However, if a person is naturalised as a Vietnamese citizen, they are required to renounce any other citizenship, unless exceptional circumstances exist. ${ }^{79}$ And,

75 See Law on Foreigner's Entry into, Exit from, Transit through and Residence in Vietnam (No 47/2014/QH13, 2014) (Vietnam) ch VI ('Law on Foreigner's Entry into, Exit from, Transit through and Residence in Vietnam 2014'). See also Law on Civil Status 2014 art 6. While provision is made for certain foreign persons to be considered for permission for permanent residence, our field work suggests that this does not occur in practice. Moreover, the process of obtaining permission to seek permanent residence is onerous, and requires a diplomatic note from the representative mission of the country of which the applicant is a citizen.

76 Kim, Park and Shukhertei (n 10) 48.

77 Law on Foreigner's Entry into, Exit from, Transit through and Residence in Vietnam 2014 art 30.

78 Priscilla Koh, 'You Can Come Home Again: Narratives of Home and Belonging among Second-Generation Viet Kieu in Vietnam' (2015) 30 Journal of Social Issues in Southeast Asia $173,181$.

792008 Nationality Law (n 69) art 19(3). See also at art 23(5). 
according to findings from our field research, these exceptional circumstances would not exist for a child of a returned marriage migrant - although we have also received some conflicting information, which suggests that this matter is an evolving issue with variable outcomes in practice.

This limitation poses problems for the children within our study that fit within the dual nationality category. Although only two children identified as having two nationalities, this issue technically arises in relation to the first group for those who have not renounced their father's nationality. Children in this category need to renounce either their Vietnamese citizenship or their foreign citizenship. Accordingly, it seems that children within our study that have both foreign and Vietnamese nationality have acquired Vietnamese citizenship through fraudulent methods of documentation, which may affect their legal status in the future. Although these children may have obtained permanent registration under the ho khao system through these means, their status remains precarious. For example, if the fraud is detected their citizenship and/or registration status may be cancelled. However, our preliminary findings also suggest that the Ministry of Justice may simply require the child to renounce his or her other citizenship without further penalty. This is another example of the ad hoc and discretionary practices that may be used to respond to individual cases.

\section{Children (from China) Who Are Undocumented}

In the fourth category, only 3 of the 206 children included within our sample were said to have no nationality. ${ }^{80}$ These children were undocumented, that is they had no documentation on their nationality. They were children of returned marriage migrants from China where, unlike Korea and Taiwan, there is no marriage migrant visa and such migration occurs informally or irregularly. ${ }^{81}$ While these children would have Chinese nationality at birth (as in Korea and Taiwan), this category is complicated by the fact that many of these women migrate back into Vietnam irregularly, and thus the children may be deemed irregular migrants within the Vietnamese context. As a result, they are very unlikely to be registered in the ho khau system because they do not have identity documents.

However, our interviewees suggested that these cases may be addressed in an ad hoc manner. For example, their mother may be allowed to register the child without documentation (or with fake documentation), and then claim the father is unknown in order to apply for Vietnamese nationality, as outlined in the discussion of the first category. While the number of children in this category included in our study is minor, the full scope of this issue within Vietnam is largely unknown but likely to increase as the Chinese 'market' expands. When considering the notion of 'degrees' of statelessness, as discussed in Part I, it is clearly arguable that these

80 It is important to note that the families and guardians of 30 of the children in our study declined to give information regarding the child's nationality. We hypothesise, but cannot confirm, that these families may be hesitant because of fraudulent efforts to obtain nationality, or because the child is in Vietnam 'illegally'.

81 Guofu Liu, Managing and Regulating Marriage Migrants in China (Report, International Organization for Migration, 2017). A copy of this document is on file with authors. The only existing Chinese law on marriage migration addresses protection mechanisms for Chinese women who participate in marriage migration, mainly to Taiwan. Chinese law did not anticipate welcoming marriage migrants into China and has yet to respond to this new phenomenon; marriage migrants who enter China do so through illegal or irregular migratory practices. 
children are at the extreme end of the spectrum as they are most vulnerable due to lack of documentation.

In this way, the legal statuses of the children of returned marriage migrants in Can Tho, Vietnam range from children who have acquired Vietnamese nationality ('Category 1'), those who have only their father's foreign nationality ('Category 2' and 'Category 4'), and those for whom it is claimed they have both a foreign and Vietnamese nationality ('Category 3'). For those in Category 2 and Category 4 de facto statelessness or lack of effective protection arises because of the child's temporary household registration status or lack of household registration. In the case of Category 4, the lack of documentation is an additional vulnerability factor. For those in Category 1, their Vietnamese nationality is potentially precarious as the child's status as a citizen of Vietnam may be revoked and their registration may be cancelled if fraudulent conduct is detected. On the other hand, administrative discretion might be exercised in their favour. They are thus at risk of de facto statelessness.

\section{NATIONAL IDENTITY: Household REgistRATION, NATIONALITY LAWS}

\section{AND STATELESSNESS IN VIETNAM}

In this part we describe first, the household registration system to further develop our argument above that many children of returned marriage migrants are at risk of de facto statelessness or lack of effective protection or nationality. We then explain Vietnam's nationality laws and approach to statelessness to assist us to move towards our conclusions.

\section{A The Household Registration System as De Facto Nationality}

In our view within Vietnam's legal system, nationality alone is not determinative of the issue of 'effective citizenship' or 'nationality'. Rather, understanding Vietnam's household registration system is critical to appreciating the barriers faced by children of returned marriage migrants in accessing or claiming social rights and protections usually associated with nationality.

Historically, socialist Vietnam has 'regulated residence and restricted movement through the ho khau system'. ${ }^{82}$ Similar to communist China, the system is intended to prevent surges in urbanisation from disrupting state planning or increasing unemployment, but also for internal security and control purposes. ${ }^{83}$ The current significance of the household registration system in the context of marriage migration in the region suggests that it is considered as a form of de facto nationality or 'local citizenship', especially in China which places less emphasis the idea of 'national' citizenship. ${ }^{84}$ We suggest this may be the case in Vietnam as

82 World Bank, Vietnam's Household Registration System (Report, June 2016) 1 ('Vietnam's Household Registration System').

83 ibid.

84 Isabelle Cheng, 'Reality or Pretense? Renouncing Nationality and Organized Hypocrisy of the Sovereignty of Taiwan' (2017) 26(4) Asian and Pacific Migration Journal 436, 437-8. In this article Isabelle Cheng argues that Taiwan and the People's Republic of China ('PRC') practice 'organized hypocrisy' in permitting the PRC to cancel the household registration of PRC marriage migrants to Taiwan (rather than their Chinese nationality as such). She contrasts the acquiescence of Vietnam to allow Vietnamese nationals to renunciate their nationality. 
well (although Vietnamese nationality as we explain below has developed in a particular way). Indeed, our preliminary findings indicate that there is more concern within Can Tho to ensure that children of returned marriage migrants are appropriately registered under the ho khau system so that they can access relevant government services, rather than obtaining Vietnamese nationality.

Residents in Vietnam must register as a 'permanent' or 'temporary' resident (as for example, the children in Category 2 above) in their respective city of residence. ${ }^{85}$ Generally, non-citizens cannot register as a 'permanent' resident in their city of residence, irrespective of their period of residence. ${ }^{86}$ The status of temporary residence also restricts their freedom of movement in contrast to permanent residents. Only Vietnamese citizens who have moved districts within Vietnam may register as a permanent resident if they have lived in the district for a period of one year (if they have moved to a suburban district) or two years (if they have moved to an urban district). ${ }^{87}$

Before the Doi Moi period, the ho khau system 'was tightly tied to access to food rations, land, housing, education, health, and employment'. ${ }^{88}$ Indeed, '[g]iven the pervasive grip of state control, lack of ho khau meant living without the rights and services afforded by the state to its citizens' (even if one was a Vietnamese citizen, albeit not registered under the system). ${ }^{89}$ Since Doi Moi, however, scholars have noted that the household registration system has become more relaxed. ${ }^{90}$ It is no longer required for the provision of food rations, for example, as these rations are no longer provided. Despite this, the ho khau system 'continues to restrict migrants and their families' access to basic services such as health and education'. ${ }^{91}$ Indeed, our findings suggest that there is currently a focus on enabling the children of returned marriage migrants to be appropriately registered so that they are able to attend primary school — rather than on ensuring that they acquire Vietnamese nationality.

Moreover, our findings suggest another concern associated with the ho khau system, namely that it has generated some flexibility in how provinces of Vietnam choose to deliver services in practice. For example, the Can Tho province has made a provincial determination to accept all children who are registered pursuant to the ho khau system to public primary schools, irrespective of whether the child is registered as a permanent resident or a temporary resident, and irrespective of the child's formal nationality in law. ${ }^{92}$ This appears to be a direct response to the children of returned marriage migrants in Can Tho. However, our interviewees suggested that these practices vary between provinces and moreover, decisions about access to services may be made on an individual basis. Further, it is unclear how lack of permanent registration may affect children in the future. We do not know, for example, what the practice will be when the children of returned

85 Law on Civil Status 2014 art 6.

86 Law on Foreigner's Entry into, Exit from, Transit through and Residence in Vietnam $2014 \mathrm{ch}$ VI: regarding temporary residence.

87 Vietnam's Household Registration System (n 82) 3.

88 ibid 4.

89 ibid.

90 Lan Anh Hoang, Gender and Agency in Migration Decision Making: Evidence from Vietnam (Working Paper Series No 115, Asia Research Institute, April 2009) 3-4.

91 ibid.

92 Sayomi Ariyawansa, Interview with Khanh Toan, Faculty of Law, Can Tho University (Can Tho, Vietnam, 3 August 2018). 
marriage migrants require access to secondary or tertiary education, or in relation to employment and military service. Research undertaken by the World Bank suggests that children with temporary registration are 'less likely to be enrolled in school at the lower and upper secondary levels', and to have greater difficulty in accessing the public health system and other government services. ${ }^{93}$ These concerns apply particularly to the returned children in Category 2 who have a foreign nationality.

\section{B Nationality and Identity}

In our view Vietnam's progressive approach to nationality (and statelessness) offers evidence of the ability to adapt to new challenges - including marriage migration and the situation of children of returned marriage migrants.

The current Constitution of the Socialist Republic of Viet Nam ('The Constitution' $)^{94}$ and nationality laws ${ }^{95}$ of Vietnam reflect socialist values, ${ }^{96}$ an 'ethnic understanding of nationality' 97 and emphasise the importance of the diaspora to the Vietnamese national identity. ${ }^{98}$ In this way, the existing legal framework in Vietnam bears out the complexities of Vietnam's colonial and postwar history, as well as the impact of several periods of mass emigration including the 'mass exodus' that occurred in the aftermath of the second Indochina conflict (1954-75). ${ }^{99}$ Relevantly, the current 'outward-looking' approach that is broadly inclusive of the rights of so-called 'overseas Vietnamese', being Vietnamese citizens and persons of Vietnamese origin who permanently reside in a foreign country, ${ }^{100}$ is relatively recent.

Vietnam has had five constitutions since $1946^{101}$ which have progressively modified the focus on socialist principles under which 'rights are circumscribed by the State's interests' 102 and the 'inseparability of citizens' rights and their duty to state and society'. 103 Whilst this 'regulatory and statist-rights regime'104 remains 'hegemonic' since the 1992 Constitution (the fourth, after the 1946, 1959

93 Vietnam's Household Registration System (n 82) 25, 26-30.

$9413^{\text {th }}$ National Assembly, 28 November 2013 (entry into force 1 January 2014) ('The Constitution').

952008 Nationality Law (n 69).

96 The Constitution (n 94) arts 2, 4.

97 Kneebone, 'Nationality and Identity in Regulation' (n 5) 14, citing 2008 Nationality Law (n 69) art 5(1).

98 The Constitution (n 94) art 18; 2008 Nationality Law (n 69) art 7.

99 Koh (n 78) 174-9.

100 See 2008 Nationality Law (n 69) art 3(3); Kneebone, 'Nationality and Identity in Regulation' (n 5) 14.

101 Bui Ngoc Son, 'The Global Origins of Vietnam's Constitutions: Text in Context' [2017](2) University of Illinois Law Review 525, 528. See generally 1946 Constitution of the Socialist Republic of Vietnam, $1^{\text {st }}$ National Assembly, adopted 9 November 1946; 1959 Constitution of the Socialist Republic of Vietnam, $2^{\text {nd }}$ National Assembly, adopted 1 January 1960; 1980 Constitution of the Socialist Republic of Vietnam, $6^{\text {th }}$ National Assembly, adopted 18 December 1980; 1992 Constitution of the Socialist Republic of Vietnam, $8^{\text {th }}$ National Assembly, adopted 15 April 1992.

102 Son (n 101) 550.

103 ibid 551.

104 ibid 554. 
and 1980 constitutions), the 1992 version continued the socialist tradition in a 'more moderate manner' in particular promoting economic liberalisation. ${ }^{105}$

Indeed, it was post Doi Moi that prompted the amendments to the 1992 Constitution. ${ }^{106}$ As a result, the Vietnamese diaspora began to be seen as 'important resources' to the state of Vietnam. ${ }^{107}$ This openness to incorporating Vietnamese emigrants (and, importantly, their descendants who were not born in Vietnam) into the nationality discourse (and laws - see, for example, art 18 in the Constitution and art 7 in the 2008 Nationality Law) necessitated a 'rehabilitation' of the Vietnamese diaspora. 'Viet Kieu' — the term used to describe Vietnamese emigrants emphasises cultural and racial heritage. ${ }^{108}$ Indeed, 'notions of nation, bloodlines and race [have been combined] into official discourse to make nationalistic claims on emigrants'. ${ }^{109}$ One can see this clearly in Vietnam's nationality laws, which invoke the consanguinity principle to link 'overseas Vietnamese "to their primordial origins, even in a globalised era of widespread long-distance mobility and out-migration"'. 110

Against this context, the phenomenon of marriage migration 'constitutes part of the contemporary out-migration trends'. ${ }^{111}$ As an issue, marriage migration 'has been written into the narrative of international integration and economic development in Vietnam's emigration policy'.112 At the national policy level, marriage migration is accepted as a valid strategy. The Vietnam Women's Union for example which previously regarded marriage migrants as opportunistic, now works closely with them on the issue. ${ }^{113}$ By contrast, a common theme in the discussion of women's role in marriage migration in Vietnamese media (noting that mass media in Vietnam is state-controlled) is the link to the nation-building project and national identity: 114

The most salient media content about marriage migration is that involving discussions and criticisms about women's sexuality and roles as wives and mothers, which encapsulate tensions around the search for national identity. According to

105 ibid 529.

106 Koh (n 78) 181.

107 ibid.

108 ibid 183 (emphasis added).

109 ibid.

110 ibid 183, citing Ivan Small, 'Embodied Economies: Vietnamese Transnational Migration and Return Regimes' (2012) 27(2) Journal of Social Issues in Southeast Asia 324, 239. See also 2008 Nationality Law (n 69) art 3(3).

111 Koh (n 78) 178.

112 Kneebone, 'Nationality and Identity in Regulation' (n 5) 14.

113 This reflects a change in response between interviews conducted in 2014 and 2015. Susan Kneebone, Interview with Anonymous, Consultant with the Vietnam Women's Union (Ho Chi Minh City, Vietnam, 3 October 2014); Susan Kneebone and Brandais York, Interview with Anonymous, Consultant with the Vietnam Women's Union (Ho Chi Minh City, Vietnam, 24 November 2015). See also Decree Detailing the Implementation of a Number of the Marriage and Family Law Regarding the Marriage and Family Relations Involving Foreign Elements (No 24/2013 ND-CP, 2013) (Vietnam), under the Marriage and Family Law of 2000 (No 22/2000/QH10, 2000), permits the Vietnam Women's Union to establish Centres of Consultancy and Assistance.

114 Danièle Bélanger, Khuat Thu Hong and Tran Giang Linh, 'Transnational Marriages between Vietnamese Women and Asian Men in Vietnamese Online Media' (2013) 8(2) Journal of Vietnamese Studies 81-84. 
the media, marriage migrant women's behaviour brings harm and shame to the 'nation' and all Vietnamese people... ${ }^{115}$

However, despite popular attitudes to marriage migration, in comparison to the 'receiving' states of Taiwan and China in particular (where the motives of marriage migrants are strongly doubted), ${ }^{116}$ Vietnam's approach at the national level appears to be more flexible. This flexibility can be seen through Vietnam's willingness to work with Taiwan for example on permitting the renunciation of nationality by Vietnamese marriage migrants in Taiwan, ${ }^{117}$ and permitting a Korean organisation, the Korean Center for United Nations (also known as 'KOCUN') 118 to work in Vietnam ${ }^{119}$ with returned marriage migrants and their families, to regularise their legal statuses.

Further, as Kneebone observes, 'the government takes a broad view about the presence of "biracial" children in the community" 120 though it is acknowledged that 'these attitudes may not filter down to the local level'. ${ }^{121}$ For example, in a Ministry of Foreign Affairs presentation in Hanoi, June 2011, it was said that:

Vietnamese language and ... culture preservation in this group of children, how to raise these children so that they can keep two culture [sic] and can actually become a bridge for the promotion of exchanges and friendship and cooperation between the people and Government of Viet Nam with the people and governments concerned. ${ }^{122}$

Despite this more flexible and pragmatic approach, the children of returned marriage migrants face many problems and barriers in Vietnam, as described in this article.

Another important feature of the 2008 Nationality Law is that it begins from a principle of 'single nationality' and while the existing laws allows for dualcitizenship in limited circumstances, ${ }^{123}$ in practice, dual-citizenship is highly

115 ibid 83.

116 Hong-Zen Wang, 'Immigration Trends and Policy Changes in Taiwan' (2011) 20(2) Asian and Pacific Migration Journal 169.

117 Cheng (n 84).

118 See 'Project Supporting Vietnamese Women Married to RoK Men' Voice of Vietnam (Online, 28 October 2016) <https://english.vov.vn/society/project-supporting-vietnamese-womenmarried-to-rok-men-335119.vov>.

119 Traditionally, Vietnam grants permission to operate in Vietnam to few non-governmental organisations.

120 Some argue that Vietnam's relative tolerance of bi-racial children (in contrast to South Korea and Japan for example) reflects earlier French colonisation experience and the later fathering of children by foreign soldiers. See Do Thi Mai Hanh, 'International Marriages in Vietnam: Issues and Suggested Solutions' in Younghee Cho et al, Legal Systems Related to International Marriage in Asia: South Korea, Taiwan, Japan, Philippines, Vietnam and Cambodia (Report, International Organization for Migration Research and Training Centre, 2013) 279-80.

121 Kneebone, 'Nationality and Identity in Regulation' (n 5) 15.

122 ibid 14.

1232008 Nationality Law (n 69) art 4. 
restricted. ${ }^{124}$ The 2008 Nationality Law appears to focus on Vietnamese ethnic identity. For example, art 3(4) provides a definition for 'Persons of Vietnamese origin residing abroad' as 'Vietnamese people who used to have Vietnamese nationality which had been determined at the time of their birth on the consanguinity principle and their offsprings and grandchildren are permanently residing in foreign countries'. This phrasing seems to suggest that even after changing nationality, a person who is of Vietnamese origin retains this as a formal status under Vietnamese law.

A concern with the culture and identity of bi-racial children of marriage migrants is reflected in the 2012 Review of Vietnamese Migration Abroad when it was said that:

These children are known as the 'mixed ethnicity Korean generation' in Viet Nam. Despite being born in Korea and having Korean nationality, they do not know the Korean language and culture but are still legally regarded as foreigners in Viet Nam. ${ }^{125}$

\section{Recognition of De Jure Statelessness in Vietnam}

While Vietnam is not a state party to the 1954 Convention or the 1961 Convention, UNHCR has acknowledged that its current nationality laws appear 'to meet a number of key international standards'. ${ }^{126}$ Indeed, the 2008 Nationality Law has been recognised as going further than previous nationality laws in addressing statelessness. However, Vietnam has been more concerned with highly politicised issues related to stateless Vietnamese in Cambodia and along the border - a relic of post-colonial ties and a long history of territory disputes in the region. ${ }^{127}$ Further, while the state has been appropriately responsive towards stateless Vietnamese marriage migrants ${ }^{128}$ there has yet to be a national policy addressing the many issues faced by the children who migrate to Vietnam with their mothers.

In relation to the Cambodian refugees, the Vietnamese government amended its nationality laws in 2008 to simplify the naturalisation process. While identity documents are typically required for naturalisation, ${ }^{129}$ pursuant to art 22 of the

124 In common with many countries in Southeast and East Asia, dual nationality is granted rarely and mainly to highly skilled foreigners: see Low Choo Chin, 'Report on Citizenship Law: China and Taiwan' (Report, European Democracy Observatory, October 2016). This was confirmed during an interview conducted in Can Tho: Sayomi Ariyawansa, Interview with Khanh Toan, Faculty of Law, Can Tho University (Can Tho, Vietnam, 3 August 2018). South Korea grants dual nationality to qualifying marriage migrants under 2010 amendments to the 2008 Nationality Law (n 69) art 6, which permits dual nationality for a marriage migrant in a 'normal marital relationship' or those who have the care of a minor child born to the marriage.

125 Vietnamese Migration Abroad (n 55) 41.

126 United Nations High Commissioner for Refugees, Submission by the United Nations High Commissioner for Refugees for the Office of the High Commissioner for Human Rights Compilation Report - Universal Periodic Review: Socialist Republic of Vietnam (Submission, June 2013) 3 <http://www.refworld.org/pdfid/51c946514.pdf> ('UNHCR Submission 2013').

127 ibid; Lyma Nguyen, 'Report on Citizenship Law: Vietnam' (Report, Global Citizenship Observatory, September 2017) $<$ http://cadmus.eui.eu/bitstream/handle/1814/47966/GLOBALCIT_CR_2017_13.pdf?seque nce $=1>$.

128 UNHCR Submission 2013 (n 126) 3. In 2014 Vietnam amended its laws as explained in the text below. Cheng (n 84) 448-49.

1292008 Nationality Law (n 69) art 20. 
2008 Nationality Law as amended: '[s]tateless persons who do not have adequate personal identification papers but have been stably residing in the Vietnamese territory for 20 years or more by the effective date of this Law and obey Vietnam's Constitution and laws will be permitted for naturalisation in Vietnam under the order, procedures and dossiers specified by the Government'. According to the UNHCR's evaluation of the 2008 Nationality Law, this enabled naturalisation 'to resolve the protracted statelessness situation affecting thousands of former Cambodian refugees' living in Vietnam for many years. ${ }^{130}$ The UNHCR found that within a few years, at least 2,300 former Cambodian refugees had been naturalised or were in the process of being naturalised as Vietnamese citizens. ${ }^{131}$ In this way, Vietnam specifically addressed one of the 'administrative obstacles to nationality' in accordance with UNHCR's statelessness mandate.

The second issue concerned women marriage migrants who became de jure stateless under Taiwan's laws on naturalisation, which required them to renounce their nationality prior to being processed for naturalisation in Taiwan. ${ }^{132}$ This issue had been noted in a study of media reports by 2006 :

Every day, the Department of Citizenship Management (Ministry of Justice) receives many documents from Vietnamese girls who apply to give up their Vietnamese citizenship [these women are not entitled to dual citizenship]. It creates great anguish to see that forty thousand Vietnamese girls so easily renounce the citizenship that attaches them to their homeland ... However, many girls, after giving up Vietnamese citizenship, break up with their husbands, get divorced, and are denied citizenship of their destination country. They then become persons without any citizenship. ${ }^{133}$

In 2008 art 23(1)(f) was added to the 2008 Nationality Law, to enable a person who has renounced Vietnamese nationality to acquire foreign nationality, but who has failed to acquire foreign nationality, to apply to restore his or her Vietnamese nationality. The UNHCR notes that as of 2012, some 2,000 returned marriage migrants had 'successfully reacquired Vietnamese [n]ationality' pursuant to this provision. ${ }^{134}$ The UNHCR especially commended Vietnam for 'addressing statelessness among former Vietnamese women, who had renounced Vietnamese nationality in order to acquire foreign nationality of their husband, but failed to obtain the new nationality and became stateless'. ${ }^{135}$ In these two scenarios, the 2008 Nationality Law went further than its predecessors in addressing the condition of de jure statelessness.

Further, when defects in the 2008 Nationality Law were exposed (it imposed a five year time limit on applying for restoration of Vietnamese nationality, which many women for good reasons were unable to meet), the Vietnamese government amended the law in 2013 to remove the restriction. ${ }^{136}$ However, as explained below, the 2008 Nationality Law did not deal with the current situation of children

130 UNHCR Submission 2013 (n 126) 3.

131 ibid.

132 Kneebone, 'Transnational Marriage Migrants and Nationality', (n 9).

133 Bélanger, Hong and Linh, (n 114), citing Dương Hải, 'Vỡ mộng cô dâu ngoại' [Disillusioned about Foreign Brides] Labor Online (30 December 2010).

134 UNHCR Submission 2013 (n 126) 3.

135 ibid.

136 (No 56/2014/QH13, 26 February 2014) (Vietnam), adjusting and supplementing some articles of the 2008 Nationality Law (n 69). 
of returned marriage migrants, even though the issue of stateless children is recognised in its laws. The 1988 Nationality Law, ${ }^{137} 1998$ Law on Vietnamese Nationality 138 and 2008 Nationality Law (the current law) all deal with the question of the nationality of a child born on Vietnamese territory to stateless parents or a child born to a Vietnamese mother and a stateless father (irrespective of place of birth), as well as the question of nationality in the case of a child who is found abandoned in Vietnam. However, these laws do not address the current situation of the children of returned marriage migrants. When the 2008 Nationality Law was amended, it did not address this issue, even though media reports prior to the enactment of the 2008 Nationality Law referred to the "mixed-blood" generation ... born of international marriages, as being a problem for the future of Vietnam'. ${ }^{139}$ For example, one report stated:

For children born from Taiwan-Vietnamese marriages (and currently living in some southern provinces), the issue of citizenship is still in question. These children came to Vietnam with their divorced mothers or were sent to Vietnam and placed in the case of their grandparents. Issues regarding birth certificates, household registrations, education, and health care are still unresolved. ${ }^{140}$

\section{CONCLUSIONS}

In our case study of the children of returned marriage migrants in the Can Tho region, we have identified that while these children are ethnically 'half Vietnamese', and presumably hold their foreign father's nationality in law, their legal status is often precarious as they often lack the appropriate ho khau or household registration, which, we have argued, under the Vietnamese legal system, amounts to 'de facto nationality'. This lack of, or difficulty in accessing, permanent household registration, means that many of the children are de facto stateless, in the sense of lacking an effective nationality. The precariousness extends also to the children who claim to have Vietnamese nationality, if it has been obtained through fraudulent means (which has occurred in many cases). We argue that de facto statelessness needs to be addressed in the same way as de jure statelessness, namely through a procedural approach. In the case of Vietnam, this would involve removing administrative obstacles to permanent household registration (and coincidentally the need to resort to fraudulent practices and $\backslash$ or to rely on discretionary decision-making). This reform would involve issuing identity documentation and establishing procedures to determine the nationality status of the child, including assistance to obtain birth certificates from the country of birth.

At the legal and policy level, there are gaps in the laws and practices which we have identified. This includes the lack of provision in the 2008 Nationality Law which specifically addresses the situation of children of returned marriage migrants, and which provides for a mother to unilaterally register her child as a Vietnamese citizen as outlined above in our discussion of art 16(2). As a

137 Law on Vietnamese Nationality (No 03/1988, 1988) (Vietnam).

138 Law on Vietnamese Nationality (No 07/1998/QH10, 1998) (Vietnam).

139 Bélanger, Hong and Linh (n 114) 96.

140 ibid 97 citing N H K, '90\% dâu Việt ở Đài Loan chưa được nhập quốc tịch” [ $90 \%$ of Vietnamese Brides in Taiwan Have Not Been Granted Taiwanese Citizenship] Dân Trí (online, 29 May 2005) <http://dantri.com.vn/xa-hoi/90-dau-viet-o-dai-loan-chua-duoc-nhapquoc-tich-57474.htm>. 
consequence, the mothers and families of children of returned marriage migrants are forced to resort to creative uses of the existing legal framework. Another gap in the laws in the lack of provision for dual nationality for such children. These are of course all matters to be debated and decided at the national level. Additionally, our research suggested a lack of consistent application of the existing legal framework at the local or provincial level. We note that the 'ad hoc' or case-by-case solutions devised at the local level point to deep disparities between law and practice.

However, in order to tackle this problem, there is a need for reliable data on the situation of the children of returned marriage migrants. Our findings support the need for further investigation into the underexplored consequence of marriage migration in this region and throughout Vietnam, and the circumstances under which children return and live in Vietnam. We note the 'newness' of this problem and the need to accommodate the long term needs of these children as they reach adulthood. Critically, while we focus here on the uncertain legal status of these children in Vietnam, there is also a great need to understand the broader social consequences of this phenomenon - including, for example, the impact of longterm separation from their fathers, who are located outside Vietnam and with whom they may have no contact. In sum, the many impacts of marriage migration on the children of returned marriage migrants are yet to be fully identified - and this information is essential to form appropriate policy responses.

Further there needs to be more awareness raising and education about this issue. We found that many families were unaware of the possible consequences of their actions in falsely identifying children as Vietnamese nationals, or about the consequences of not registering a child under the ho khau system.

Finally, this problem also points to issues surrounding divorce and custody proceedings in the destination state. These are beyond the scope of this paper, but they are the primary source of the problem and point to the need for bilateral and regional approaches to tackle the problem. 